\title{
FRESH PRODUCE RETAIL PRICE COMPARISONS IN TRINIDAD AND TOBAGO
}

\section{W. Ardon Iton ${ }^{1}$ and Govind Seepersad ${ }^{2}$}

\author{
${ }^{1,2}$ Department of Agricultural Economics and Extension, \\ Faculty of Food and Agriculture, University of the West Indies, \\ St. Augustine, Trinidad. \\ 1iton.ardon@gmail.com, ${ }^{2}$ Govind@seepersad.org
}

\begin{abstract}
As the competitive landscape of the food and grocery retailing sector in Trinidad and Tobago is being transformed and consumers are separated from producers, shoppers are more reliant on price/quality cues in making their purchase decisions. The purpose of this study is to identify the retail outlet with the lowest and or highest price for a selected number of fresh produce items, in an effort to direct shoppers to relatively cheap nutritious sources of fresh produce. ANOVA and the Games-Howell test were the analytical procedures used. The ANOVA results indicated that there is statistical difference for all the items at the different retail outlets - farmers' markets, roadside markets, public markets and supermarkets. The Games-Howell results obtained indicated that the supermarket mean prices were the highest for all items. Shoppers who purchased pineapple at the farmer's market instead of the supermarket in 2016 could have potentially achieved the greatest savings of \$6.52/kg.
\end{abstract}

Keywords: Fresh produce, Retail prices, ANOVA, Games-Howell Test, Trinidad and Tobago shoppers.

(JEL Classification: C12, Q13, M31)

\section{Introduction}

Despite the overwhelming evidence in the diet/health literature of the numerous benefits from an adequate daily consumption level of fresh produce, in the Caribbean where there is supposed to be an abundant supply, many populations fail to achieve the recommended daily intake levels. As a direct result there has been increasing levels of Non-Communicable Diseases (NCDs) being experienced globally, including the Caribbean. In 2015 the Global Burden of Disease Study reported that the total deaths from NCDs reached 39.8 million. Table 1 illustrates the top five causes of death in Trinidad and Tobago (T\&T) as reported by the World Health Organization (WHO) in 2014. As can be seen in this table cardiovascular diseases top the list, while injuries come in at number 5. Of the 13,000 deaths reported, $80 \%$ was attributed to NCDs. Root Crops and fruits and vegetables are rich sources of fibre, antioxidants, and phytochemicals that have beneficial health effects, such as aiding in the prevention of many chronic diseases, including type-2 diabetes when consumed. Increasing their consumption is one means of reducing the level of NCDs in many developing countries.

Table 1: Top five causes of death in T\&T

\begin{tabular}{|l|c|}
\hline diseases/injuries & Percent of total deaths \\
\hline cardiovascular & 32 \\
\hline cancers & 16 \\
\hline other ncds & 15 \\
\hline diabetes & 14 \\
\hline injuries & 11 \\
\hline \multicolumn{2}{|c|}{ Source: WHO Non-communicable Diseases Country Profiles, 2014 }
\end{tabular}

Traditionally, in the Caribbean, as was the case in most developing countries, fresh produce retailing was limited to public markets, roadside stands and at farm gate. However, in the last few decades consumers in developing countries in general, and Trinidad and Tobago specifically, have been offered increased options - supermarkets, public markets, roadside stands, farmers' markets and at farm gate - from which to purchase fresh produce. While supermarkets provide potential customers the benefits of "one stop" shopping and a pleasant shopping environment, in many developing countries price of goods is a major determinant of where one shops. The purpose of this study is to compare the retail prices for a selected number of fresh produce items in an attempt to identify the outlet with the highest or lowest price. The products selected for the study were from the Staples (Dasheen and Sweet Potato) and Fruits and Vegetables food groups (Pineapple, Watermelon, Cucumber and Pumpkin,) over the period January to December 2016 in Trinidad and Tobago.

Recently, several studies have suggested that healthier foods and diets are more expensive than less healthy options (Roa et al 2013, and Wiggins \& Keats 2015). In a study titled "Obtaining Fruit and Vegetables for the Lowest Prices: Pricing Survey of Different Outlets and Geographical Analysis of Competition Effects" Pearson et.al (2014) state "Perhaps the most consistently noted barrier to adequate consumption of fruits and vegetables is cost". Appleton et.al (2016) focusing on just vegetables alone (i.e. not fruit and vegetables, just vegetable) suggest that besides individual preferences, higher vegetable consumption in adults is also related to increased availability and reduced cost, and low consumption is 
largely associated with lower socio-economic status lower income, living in a more deprived area or lower income neighborhood (an indirect measure of socio-economic status) and lower education. Hence, being able to direct customers to cheap nutritious sources of fresh produce should therefore contribute to increased purchase and consumption levels. This study is an attempt to compare the prices of cucumber, pumpkin, pineapple, watermelon, dasheen and sweet potato at supermarkets, public markets, roadside vegetable/fruit stands and farmers' markets in T\&T in an attempt to identify the retail outlet with the lowest and/or highest prices.

Minten and Reardon (2008) in a study titled "Food Prices, Quality, and Quality's Pricing in Supermarkets versus Traditional Markets in Developing Countries" looked at survey-based evidence from ten developing countries plus primary data from Madagascar. They concluded that there is a stable and predictable pattern in supermarket pricing and quality offerings versus traditional markets, as follows:

- In the early stages, supermarkets are better than traditional retailers by charging lower prices for processed products-taking advantage of procurement systems that allow economies of scale. The poor consumers take advantage of this to buy processed foods and semiprocessed foods from supermarkets.

- In the early stages, supermarkets sell especially vegetables more expensive than do traditional retailers. Eventually, they do reduce their prices and compete on fruit and eventually vegetable prices.

- Supermarkets in the early stages tend to focus on packaged and high-quality products, but as time goes by, they extend their quality range to attract the mass market.

- Recognizing the data limitations, supermarkets tend to differentiate price based on quality. However, in the case of potatoes in Ecuador, they thought supermarkets provided better quality and lower prices.

They however suggested that these were early findings and should be verified at a later date adjusting price to take account of transaction costs. Since the "Supermarket Revolution" can be considered to be still in the early stages in the Caribbean, for purpose of this study we hypothesize that supermarket prices would be highest.

Several studies that compare prices at farmers' markets and supermarkets, Sommer et al (1980) and Swenson (2012) for example, suggest that fresh produce prices are lower at farmers' markets. Swenson (2012) compared the prices of sweet onions, broccoli, Romaine lettuce, butternut squash, vine ripened tomatoes and Navel oranges at farmers' markets and supermarkets in San Luis Obispo County, California over a five week period. She concluded, "The hypothesis that farmers' markets would have lower prices on average than their paired supermarkets was proven to be correct through intensive price analyses". Based on the six chosen commodities, the average price at the farmers' markets was 25 cents lower than at the supermarkets.

As Valpiani et al. (2016) state "Whether direct farmerto-consumer outlets compete with supermarkets on produce prices remains an empirical question". Consequently, the approach and analytical rigor applied will be very dependent on the researcher. Based on the review provided above, the problems that will be addressed in this study are as follows:

(1) To compute the average prices for cucumber, pumpkin, watermelon, pineapple, sweet potato and dasheen at the four retail outlets;

(2) To test if the mean prices are statistically different at the different retail outlets.

$\boldsymbol{H O}_{\boldsymbol{I}}$ : The farmers' market, public market, roadside market and supermarket mean prices are equal;

$\boldsymbol{H A}_{\mathbf{l}}$ : The farmers' market, public market, roadside market and supermarket prices are not equal,

(3) If the prices are not equal, to try and identify the outlet with the lowest and or highest price;

\section{MATERIAL AND METHOD}

Food price comparison studies are plagued with problems. Minten et al (2009) state "Three important issues in traditional food retail markets in India, as well as in a number of other developing countries, exist that might complicate the measurement of prices. They include bargaining, differential pricing, and cheating. First, prices are mostly not posted and bargaining might take place between the buyer and the seller before they settle on a price, especially for fresh produce". Further complicating things is the issue of similar quality, especially in the case of fresh produce, when comparisons are made between supermarkets and traditional outlets.

Being cognizant of the problems stated above this study utilized data collected by the National Agricultural Marketing and Development Corporation (NAMDEVCO), of Trinidad and Tobago. NAMDEVCO, a State Agency, manages the wholesale markets in T\&T and is well positioned to collect the prices for a selected range of products in these markets regularly. To complement the data from the wholesale markets, their trained data enumerators also collect data at other selected retail outlets for agricultural products. This study uses monthly data $\left(\mathrm{TT} \$ / \mathrm{kg}^{1}\right.$ ) for the period January 2016 to December 2016 from the National Agricultural Marketing Information Systems (NAMIS), a part of NAMDEVCO.

The study uses the one-way analysis of variance (ANOVA) to see if there was a statistically significant difference between the mean prices of the fresh produce items at the different retail outlets.

$1 \quad \mathrm{US} \$ 1.00=\mathrm{TT} \$ 6.73$ 
The ANOVA is an analytical procedure that uses the variance to determine whether means are significantly different, by apportioning the variances between the groups of means versus the variance within the groups (the null hypothesis Ho: $\mu 1=\mu 2=\mu 3=\ldots=\mu \mathrm{k}$, where $\mathrm{k}=$ the number of groups). There are a number of a posteriori or post hoc tests, run after a significant ANOVA, to determine which differences are significant. In the general case of multiple pairwise comparisons where we compare each of the pairs we make $\mathrm{K}(\mathrm{K}$ 1)/2 comparisons (where $K$ is the number of groups). As Field (2009), page 375 recommends, the GamesHowell test should be carried out when one is not sure that the homogeneity of variance assumption holds. Consequently, this was the a posteriori test used to identify the retail outlet with the lowest price and or highest price. The relevant data were analyzed using SPSS version 21.

\section{RESULTS AND DISCUSSION}

Figure 1 illustrates the average prices over the period January 2016 to December 2016 for the selected products at the various retail outlets. As is observed in the chart, the farmers' markets seem to have the lowest prices for the products except for pumpkin, where the lowest price is obtained in the public market. The supermarket appears to have the highest price for all of the products.

Figure 1: Average prices of the products at the retail outlets: January 2016 to December 2016

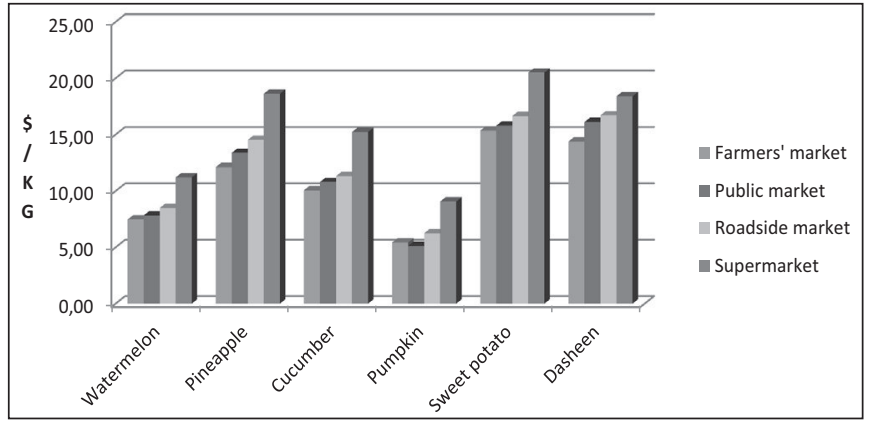

Table 2 illustrates the descriptive statistics of the various prices. As can be observed from this table, sweet potato at the supermarket had the highest mean price while public market for pumpkin the lowest mean price. The standard deviation is a measure that is used to quantify the amount of variation of a set of data values. A low standard deviation indicates that the data points tend to be close to the mean of the set, while a high standard deviation indicates that the data points are spread out over a wider range of values. It is worthy to note that the standard deviation of the public market mean price for watermelon was the lowest standard deviation, while the supermarket mean price for sweet potato had the highest standard deviation.
Table 2: Retail market prices for the period January to December 2016 descriptive statistics

\begin{tabular}{|c|c|c|c|}
\hline Retail market prices & Mean & $\begin{array}{c}\text { Std. } \\
\text { Deviation }\end{array}$ & Std. Error \\
\hline \multicolumn{4}{|l|}{ Watermelon } \\
\hline Farmers' market & 7.47 & 1.63 & 0.47 \\
\hline Public market & 7.83 & 0.60 & 0.17 \\
\hline Roadside stand & 8.49 & 0.85 & 0.25 \\
\hline Supermarket & 11.21 & 0.78 & 0.23 \\
\hline \multicolumn{4}{|l|}{ Pineapple } \\
\hline Farmers' market & 12.11 & 1.56 & 0.43 \\
\hline Public market & 13.38 & 0.61 & 0.18 \\
\hline Roadside stand & 14.53 & 0.85 & 0.25 \\
\hline Supermarket & 18.63 & 0.82 & 0.24 \\
\hline \multicolumn{4}{|l|}{ Cucumber } \\
\hline Farmers' market & 10.07 & 1.63 & 0.47 \\
\hline Public market & 10.80 & 1.76 & 0.51 \\
\hline Roadside stand & 11.32 & 2.19 & 0.63 \\
\hline Supermarket & 15.23 & 2.32 & 0.67 \\
\hline \multicolumn{4}{|l|}{ Pumpkin } \\
\hline Farmers' market & 5.43 & 0.76 & 0.22 \\
\hline Public market & 5.12 & 0.80 & 0.23 \\
\hline Roadside stand & 6.25 & 0.71 & 0.21 \\
\hline Supermarket & 9.07 & 1.25 & 0.36 \\
\hline \multicolumn{4}{|l|}{ Sweet Potato } \\
\hline Farmers' market & 15.35 & 2.37 & 0.68 \\
\hline Public market & 15.79 & 2.32 & 0.67 \\
\hline Roadside stand & 16.65 & 2.83 & 0.82 \\
\hline Supermarket & 20.50 & 3.62 & 1.04 \\
\hline \multicolumn{4}{|l|}{ Dasheen } \\
\hline Farmers' market & 14.38 & 0.97 & 0.28 \\
\hline Public market & 16.11 & 1.25 & 0.36 \\
\hline Roadside stand & 16.71 & 1.42 & 0.41 \\
\hline Supermarket & 18.40 & 1.84 & 0.53 \\
\hline
\end{tabular}

An assumption of the ANOVA test is that each group of the independent variable has the same variance. Moderate deviations from this assumption of equal variance do not seriously affect the results in ANOVA, but we will normally check to see if the assumption holds. Table 3 shows the results of the Levene's Test for equality of variances. As is observed the p-value of the test statistic obtained was greater than 0.05 in all cases. As a result the null hypotheses cannot be rejected for pineapple, watermelon, cucumber, pumpkin, sweet potato and dasheen, so we can therefore proceed for the ANOVA test on the assumption of equality of variances. 
Table 3:

Levene's Test for homogeneity of variances results for the products

\begin{tabular}{|l|c|c|c|c|}
\hline Products & $\begin{array}{c}\text { Levene } \\
\text { Statistic }\end{array}$ & df1 & df2 & Sig \\
\hline Watermelon & 1.253 & 3 & 44 & 0.302 \\
\hline Pineapple & 0.639 & 3 & 44 & 0.594 \\
\hline Cucumber & 0.441 & 3 & 44 & 0.725 \\
\hline Pumpkin & 0.858 & 3 & 44 & 0.470 \\
\hline Sweet Potato & 0.943 & 3 & 44 & 0.428 \\
\hline Dasheen & 1.737 & 3 & 44 & 0.173 \\
\hline
\end{tabular}

Table 4 illustrates the ANOVA results for the six fresh produce items. The F-statistics obtained are statistically significant at the $\mathrm{P}<0.05$ level. The null hypothesis that there is no significant difference between the average prices at the various outlets is therefore rejected. The data therefore suggest there is a statistically significant difference between the retail prices for the products at the different outlets.

The results of the ANOVA test do not inform us of the retail outlet with the lowest price. A cursory look at the mean prices as displayed in figure 1 suggests that the farmers' market prices are lowest and the supermarket prices are highest. The Games-Howell test is one of a number of a posteriori or post hoc tests, run after a significant ANOVA to help to identify which of the comparisons are lowest or highest. The Games-Howell test does not rely on equal variance and sample size and as a result was used here.

Table 4: ANOVA test results

\begin{tabular}{|c|c|c|c|c|c|}
\hline Watermelon & Sum of squares & $\mathrm{df}$ & Mean Square & $\mathrm{F}$ & Sig. \\
\hline \multirow{3}{*}{$\begin{array}{l}\text { Between Groups } \\
\text { Within Groups } \\
\text { Total }\end{array}$} & 103.155 & 3 & \multirow{3}{*}{$\begin{array}{c}34.385 \\
1.088\end{array}$} & \multirow{3}{*}{31.616} & \multirow{3}{*}{.000} \\
\hline & 47.854 & 44 & & & \\
\hline & 151.009 & 47 & & & \\
\hline Pineapple & Sum of squares & df & Mean Square & $\mathrm{F}$ & Sig. \\
\hline \multirow{3}{*}{$\begin{array}{l}\text { Between Groups } \\
\text { Within Groups } \\
\text { Total }\end{array}$} & 286.689 & 3 & \multirow{3}{*}{$\begin{array}{c}95.563 \\
1.001\end{array}$} & \multirow{3}{*}{95.425} & \multirow{3}{*}{.000} \\
\hline & 44.064 & 44 & & & \\
\hline & 330.753 & 47 & & & \\
\hline Cucumber & Sum of squares & df & Mean Square & $\mathrm{F}$ & Sig. \\
\hline \multirow{3}{*}{$\begin{array}{l}\text { Between Groups } \\
\text { Within Groups } \\
\text { Total }\end{array}$} & 191.650 & 3 & \multirow{3}{*}{$\begin{array}{l}63.883 \\
3.976\end{array}$} & \multirow{3}{*}{16.068} & \multirow{3}{*}{.000} \\
\hline & 174.937 & 44 & & & \\
\hline & 366.587 & 47 & & & \\
\hline Pumpkin & Sum of squares & df & Mean Square & $\mathrm{F}$ & Sig. \\
\hline \multirow{3}{*}{$\begin{array}{l}\text { Between Groups } \\
\text { Within Groups } \\
\text { Total }\end{array}$} & 116.789 & 3 & \multirow{3}{*}{$\begin{array}{c}38.930 \\
0.821\end{array}$} & \multirow{3}{*}{47.392} & \multirow{3}{*}{.000} \\
\hline & 36.143 & 44 & & & \\
\hline & 152.932 & 47 & & & \\
\hline Sweet Potato & Sum of squares & df & Mean Square & $\mathrm{F}$ & Sig. \\
\hline \multirow{3}{*}{$\begin{array}{l}\text { Between Groups } \\
\text { Within Groups } \\
\text { Total }\end{array}$} & 197.960 & 3 & \multirow{3}{*}{$\begin{array}{l}65.987 \\
8.023\end{array}$} & \multirow{3}{*}{8.225} & \multirow{3}{*}{.000} \\
\hline & 353.011 & 44 & & & \\
\hline & 550.971 & 47 & & & \\
\hline Dasheen & Sum of squares & df & Mean Square & $\mathrm{F}$ & Sig. \\
\hline \multirow{3}{*}{$\begin{array}{l}\text { Between Groups } \\
\text { Within Groups } \\
\text { Total }\end{array}$} & 99.593 & 3 & \multirow{3}{*}{$\begin{array}{c}33.198 \\
1.979\end{array}$} & \multirow{3}{*}{16.776} & \multirow{3}{*}{.000} \\
\hline & 87.069 & 44 & & & \\
\hline & 186.662 & 47 & & & \\
\hline
\end{tabular}

Table 5 illustrates a summary of the Games-Howell test results for the selected products. The results suggest that the farmers' market mean price and the supermarket price are significantly different for all of the fresh produce items. Similarly, the mean public market price and supermarket price are significantly different for all of the produce items with all p-values less than 0.05 . Also, the results of the test in table 5 suggest there is no statistically significant difference between the farmers' market and public market mean prices except for dasheen. In the case of dasheen there is no statistical difference between the roadside market and supermarket mean price and public market and roadside market mean price, while there is statistically significant difference for all the other dasheen retail outlet price comparisons. For pineapple and pumpkin there is statistical difference between the public market and the roadside market mean prices. In the case of pineapple there is statistically significant difference between the farmers' market and roadside markets mean prices.

Table 5:

Summary of Games-Howell post hoc Multiple Comparisons test results

\begin{tabular}{|l|c|c|c|c|c|c|}
\hline test & $\begin{array}{c}\text { water- } \\
\text { melon }\end{array}$ & pineapple & cucumber & pumpkin & $\begin{array}{c}\text { sweet } \\
\text { potato }\end{array}$ & dasheen \\
\hline fm-pm & & & & & & $*$ \\
\hline fm-rm & & $*$ & & & & $*$ \\
\hline fm-sm & $*$ & $*$ & $*$ & $*$ & $*$ & $*$ \\
\hline pm-rm & & $*$ & & $*$ & & $*$ \\
\hline pm-sm & $*$ & $*$ & $*$ & $*$ & $*$ & $*$ \\
\hline rm-sm & $*$ & $*$ & $*$ & $*$ & $*$ & \\
\hline
\end{tabular}

${ }^{*}$ The mean difference is significant at the 0.05 level

Where: $\boldsymbol{F M}=$ farmers' market; $\boldsymbol{P M}=$ public market; $\boldsymbol{R M}=$ roadside market; $S M=$ supermarke

The results of the study do support the view that the mean supermarket price is highest. Hence, an examination of the difference between the supermarket mean price and the other outlet prices should provide an indication of potential savings for shoppers that purchased the items from the other outlets instead of the supermarket. Table 6 illustrates the differences of the mean supermarket price from the mean farmers' market price for the selected items in an attempt to illustrate the potential savings for shoppers that purchased the items at the farmers' market versus the supermarket in 2016. As is observed in this table the largest savings was for pineapple of $\$ 6.52 / \mathrm{kg}$. An examination of the difference of the mean supermarket price from all the other mean market prices indicate that the smallest difference was for dasheen between the roadside market and supermarket - mean supermarket price minus mean roadside market price $\$ 1.69 / \mathrm{kg}$. An examination of table 5 shows that the mean supermarket price was not statistically different from the mean roadside market price for dasheen. 
Table 6: The differences of the mean supermarket price from the mean farmers' market price

\begin{tabular}{|l|c|c|}
\hline Product & $\begin{array}{c}\text { Supermarket - Farmers' } \\
\text { market price }\end{array}$ & Potential savings $(\$ / \mathrm{kg})$ \\
\hline Watermelon & $\$ 11.21-\$ 7.74$ & $\$ 3.74$ \\
\hline Pineapple & $\$ 18.63-\$ 12.11$ & $\$ 6.52$ \\
\hline Cucumber & $\$ 15.23-\$ 10.07$ & $\$ 5.16$ \\
\hline Pumpkin & $\$ 9.07-\$ 5.43$ & $\$ 3.64$ \\
\hline Sweet potato & $\$ 20.50-\$ 15.35$ & $\$ 5.15$ \\
\hline Dasheen & $\$ 18.40-\$ 14.38$ & $\$ 4.02$ \\
\hline
\end{tabular}

Research suggests several reasons for low levels of fresh produce consumption ranging from taste, socioeconomic status and education, however, ability to buy is particularly important in many developing countries. As the food retailing landscape in these countries are transformed and shoppers are offered an expanded range of options, making decisions become more complex. Being able to identify cheap nutritious sources of fresh produce is a fundamental intervention needed in an effort to facilitate increased purchase and consumption.

The ANOVA results for this study suggest that there is statistical difference between the mean market prices of all the produce items analyzed at the different outlets. This study found that for the selected fresh produce items the price at the supermarket - modern retail - was higher than the other retail outlets. This result is opposite to that of Minten et al (2010). In the case of pineapple shoppers who purchased at the farmer's market instead of the supermarket in 2016 could have potentially achieved the greatest savings of $\$ 6.52$ / $\mathrm{kg}$ while shoppers of dasheen at roadside markets instead of supermarkets would have received the smallest potential savings of $\$ 1.69 / \mathrm{kg}$. However, it is important to note that there was no statistically significant difference between the mean price at the farmers' market, roadside market and the public market for pumpkin, cucumber, sweet potato and watermelon. Also, in the case of dasheen while the farmer's market means price was statistically different (less) than the other outlets there was no statistical difference between the roadside market and public market mean prices. In the case of pineapple there was no statistical difference between the mean farmer's market price and the public market, while the roadside market was statistically different from all other markets.

These findings are significant to both marketers and consumers. From a theoretical perspective marketers are provided with an indication of the price differences that exist between the different outlets. This information could be useful to them, especially the small operators, in developing countries as they develop their marketing strategies. In T\&T, like many other Caribbean countries, the pricing strategy of small operators for many agricultural products is not very scientific, but based more on "gut feelings" of what the market can bear. If this information promotes the use of more science based pricing methods, for example cost-plus pricing, which results in lower prices of the fresh produce, the study would have served a useful purpose. As Darian \& Tucci (2013) point out the most important factors that would make it more likely that the respondent would eat more vegetables are "If vegetables cost less" and "If vegetables tasted better". Helping to identify where cost savings can be had when purchasing vegetables should therefore be useful information for shoppers.

For fresh produce that a barrier to consumption is financial cost, to achieve the desired goal of increased purchase and consumption, some consideration should be given to interventions that focus on lowering the cost. Various studies have looked at marketing and or pricing strategies on the choice of food in general and vegetables specifically in developed countries, for example Darian \& Tucci (2013); Waterlander et. al. (2012), French (2003), French et al (1997), however to date to the best of our knowledge no such study has been done for T\&T. Further research on the comparison of food prices between modern and traditional retail outlets is required in an endeavor to guide food policy development in $\mathrm{T} \& \mathrm{~T}$ and the wider Caribbean.

\section{REFERENCES}

Appleton KM, Hemingway A, Saulais L, Dinnella C, Monteleone E, Depezay L, Morizet D, Perez-Cueto F J A, Bevan A, Hartwell H. (2016). Increasing vegetable intakes: rationale and systematic review of published interventions. European Journal of Nutrition 55: pp. 869-896

Claro, J. January 2011. "Vermont Farmers' Markets and Grocery Stores: A Price Comparison.” Northeast Organic Farming Association of Vermont.

Darian JC, Tucci L (2013) Developing marketing strategies to increase vegetable consumption. Journal of Consumer Marketing 5:427-435

Field, A. (2009). Discovering Statistics Using SPSS. SAGE Publications Ltd.

French, S. A., (1997), Pricing effects on food choice. Journal of Nutrition. 133, 841S-843S.

French, S. A., Story, M., Jeffery, R. W., Snyder, P., Eisenberg, M., Sidebottom, A. \& Murray, D. (1997), Pricing strategy to promote fruit and vegetable purchase in high school cafeterias. Journal of American Dietary Association. 97: 1008-1010.

Hardesty, S.D., and P. Leff. 2009. "Determining Marketing Costs and Returns in Alternative Marketing Channels," Renewable Agriculture and Food Systems, Vol. 25: pp. 24-34.

Long, J., M.A. Sounny-Slitine, K. Castles, J. Curran, H. Glaser, E. Hoyer, W. Moore, L. Morse, M. O’Hara, and B. Parafina. 2013. "Toward an Applied Methodology for Price Comparison Studies of Farmers' Markets and Competing Retailers at the Local Scale," Journal of Agriculture, Food Systems, and Community Development, Vol. 3, pp. 95-119.

Lyon, P., V. Collie, E. Kvarnbrink, and A. Colquhoun. (2008). Shopping at the farmers' market: consumers and their perspectives. Journal of Foodservice, 20, 21-30

Martinez, S. W. (2015) Fresh Apple and Tomato Prices At Direct Marketing Outlets Versus Competing Retailers In The U.S. MidAtlantic Region. Journal of Business and Economic Research, 13(4): 241-252. 
McGuirt, J.T., S.B. Jilcott, H. Liu, and A.S. Ammerman. (2011). "Produce Price Savings for Consumers at Farmers' Markets Compared to Supermarkets in North Carolina," Journal of Hunger and Environmental Nutrition, Vol. 6, pp. 86-98.

Minten, B. and Reardon, T. (2008). Food prices, quality and quality's pricing in supermarkets versus traditional markets in developing countries. Review of Agricultural Economics, 30(3): 480-490.

Minten, B., Reardon, T. and R. Sutradhar (2009). Food prices and Modern Retail: The Case of Delhi. May 13, 2017. https://www. researchgate.net/publication/222652709

Pirog, Rich, and Nick McCann. December 2009. "Is Local Food More Expensive?: A Consumer Price Perspective on Local and Non-Local Foods Purchased in Iowa." Leopold Center for Sustainable Agriculture, Ames, IA.

Rao, M., A. Afshin, G. Singh, and D. Mozaffarian. (2013). Do healthier foods and diet patterns cost more than less healthy options? A systematic review and metaanalysis. BMJ Open 3 (12): e004277. doi:10.1136/bmjopen- 2013-004277. http://dx.doi. org/10.1136/bmjopen-2013-004277.

Reardon, T., J-M. Codron, L. Busch, J. Bingen, and C. Harris. 2001. Global change in agrifood grades and standards: Agribusiness strategic responses in developing countries. International Food and Agribusiness Management Review 2(3), 195-205.

Reardon, T., C.P. Timmer, C.B. Barrett, and J. Berdegué. 2003. The rise of supermarkets in Africa, Asia, and Latin America. American Journal of Agricultural Economics 85(5), 1140-1146.

Reardon, T. and R. Hopkins. 2006. "The Supermarket Revolution in Developing Countries: Policies to Address Emerging Tensions among Supermarkets, Suppliers, and Traditional Retailers," European Journal of Development Research, 18(4), 522-545.

Reardon, T., C.B. Barrett, J.A. Berdegué, and J.F.M. Swinnen. (2009). Agrifood Industry

Transformation and Small Farmers in Developing Countries. World Development 37(11),

1717-1727.

Sommer, R., M. Wing, and S. Aitkens. (1980). "Price Savings to Consumers at Farmers' Markets," The Journal of Consumer Affairs, Vol. 14, pp. 452-462.

Swenson, P. J. (2012). Paired Price Comparisons of Farmers' Market and Supermarket Produce in San Luis Obispo County. California Polytechnic State University.

Valpiani, N.H; P.E. Wilde; B. L. Rogers and H. G. Stewart (2016). Price Differences across Farmers' Markets, Roadside Stands, and Supermarkets in North Carolina. Applied Economic Perspectives and Policy, vol. 38 (2) pp. 276-291

Waterlander W. E, Ingrid HM Steenhuis, Michiel R de Boer, Albertine J Schuit and Jacob C Seidell ; (2012) The effects of a $25 \%$ discount on fruits and vegetables: results of a randomized trial in a three-dimensional web-based supermarket. International Journal of Behavioral Nutrition and Physical Activity, 9:11

Weatherspoon D. D., and Reardon T., (2003). The Rise of Supermarkets in Africa: Implications for Agrifood Systems and the Rural Poor. Development Policy Review, 21 (3), 333-355.

Wiggins S. and S. Keats. (2010). The rising cost of a healthy diet: Changing relative prices of foods in high-income and emerging economies. Accessed May 13, 2017. https://www.odi.org/sites/odi. org.uk/files/odi-assets/publications-opinion-files/9580.pdf 


\title{
OWNERSHIP STRUCTURES WITHIN HUNGARIAN FAMILY BUSINESSES - THEORIES AND PRACTICE
}

\author{
Júlia Tobak \\ University of Debrecen Faculty of Economics and Business Institute of Applied Economic Sciences \\ tobak.julia@econ.unideb.hu
}

\begin{abstract}
We can talk about family business if the notions of family, ownership and business are closely connected to each other, namely if the business is in the possession of the family, managed and controlled by the family members. A family owned company is a business where a family has the majority ownership and/or the majority management and at least one family member actively works in the firm, the family owns the business. The study contains the results of research on ownership structure of family owned businesses. The examined family businesses are interested in longterm preservation of values, thus succession of generations plays a key role in their case. They attaches great importance how the ownership structure develops. The methotology to know more about the ownership structure of family businesses 11 expert interviews were made between november 2016 and september 2017 with owners and next generations of family owned agri-food enterprises in Hungary. A case study has been prepared too in this topic with the participation of companies with different activities (production, service, trade). In order to classify the analysed companies six categories of ownership were developed. These are non-owner, emotional owner, partial owner, controlling owner, majority owner and exclusive/ sole owner. Each generation of the analysed FBs were classified to these categories. According to the results the analysed family owned companies even are sharing the property within family. There are only two interviewed companies whose case we can talk about exclusive/sole ownership.
\end{abstract}

Keywords: Generation, Expert Interviews, Ownership Categories

(JEL Classification: G32)

\section{Introduction}

The family business form is popular all over the world. But what is family business? Several countries, many definitions, but the essence is the same. M. CANO-RUBIO et al. (2017) examined the lack of a standard definition of FBs (Family Business). Their work analyse and publicise many definitions of family firms. Basing their study and according to Ramadani-Hoy (2015) and DE MASSIS et al. (2012) the most commonly used concepts/ terms/expression in literatures in connection with FBs (Family Business) definitions are the followings: ownership, management, directorship, self-identification, multiple generations, intra family succession intention.

We can talk about family businesses if the notions of family, ownership and business are closely connected to each other, namely if the business is in the possession of the family, managed and controlled by the family members.

Based on the work of Mandl (2008) And Csákné (2012) the three most important element of comprehensive definition of family businesses are the ownership, the participation in management and the transfer or the intent of the transfer between generations.

In short, a family business is a business where a family has the majority ownership and/or the majority management and at least one family member actively works in the firm, the family owns the business.
CHU (2011) analysed factors influencing the business's achievement paying attention to family management and control and the size of the business.

According To Chu (2011) And Giovanni (2010) the indicators of achievement in the business are the most appropriate for measuring effectiveness. In striving economies the capital markets are not perfect and the proportion of debt-own assets is usually high, thus there is a strong connection to achievement and risk.

A survey of 240 state enterprises in Thailand supported the fact that in the case of family ownership there is a more positive relation between the Return On Assets (ROA) ratio of the enterprise and the net sales revenues of sales than in the case of enterprises that are not family-owned, which points to a greater and better achievement, to the will to perform (CHU, 2011).

CHU (2011) used the data of 786 family businesses from Taiwan in his study. According to his view a company is stronger if the family members are present as chairmen, corporate executives, presidents or managers. If the family members do not participate in the management and control of the business, then the company becomes weaker. The results of his study show that the positive effects of family ownership are realised with a greater probability if the family ownership is paired with family management and control. The relation between family ownership and business achievement is stronger in the case of small or medium businesses, than in bigger corporations. In his view the determinant of success is the output of the business, thus 
one consequence of power of family. Performance depends on internal and external conditions. The characteristics of business, and especially the size of the company influences the relation between family ownership and profitability. The effect of family ownership on profit depends on family management and control and the size of the company.

As the definition reported by ARREGLE et al. (2012) stated that a firm only could be considered as a FB if the „ownership by persons outside the family should not exceed $49 \%$ ". Also as stated in a study about family-controlled firms "a family business is one in which at least $50.1 \%$ is owned by one family" (CALABRÒ et al., 2016).

According to RANTANEN-JUSSILA (2011) the F-CPO (Family-Collective Psychological Ownership) phenomena does not only represent the potential influence of the family, it also indicates real effect. The F-CPO takes several correlations into consideration, such as collectivity, identification and interdependency among family members in business correlations. Reasons for such Psychological Possessions can exceed the motives of social-emotional affluence and can help in enlarging the present-day knowledge concerning the non-exclusively financial aims of the family business.

'This business is mine.'

This could be the key sentence for this structure, since the Psychological Possession is a state of mind which is activated by the need for owning. This kind of emotion can emerge in connection with material or immaterial goods.

From the aspect of psychological possession, the family can be interpreted as a social system, while the business can be considered as a social and physical organisation. Namely, business is in the family.

The F-CPO - scale can be characterised by the following statements:

- We (my family and me) feel that the business is ours.

- We (my family and me) are strongly attached to the common business possession.

- We (my family and me) share the feeling that the business - as a whole - belongs to the family.

On the basis of the paper by Randel S. CARLOCK (2012) in THE TIMES the flow of ownership and control between generations - passing the baton - is a challenge which family businesses have to face. Unfortunately, several family businesses do not work out a plan for the further operation of the business. However, this is one element of the strategic planning which is inevitable for the future operation.

All family businesses whose founders created the unity of aims concerning the acquisition of values and the future want to hand over business values and attitude directly to their children, namely would like to pass over their experiences inside the family. The reality and immediacy of generation succession has become a necessary current issue (Nagy, 2007).

There are expected and unexpected events within an operation of family business. The succession is a foreseeable fact while the events like birth, death, marriage, divorce or retirement are unpredictable and may upset the family balance. These kind of changes forces the family businesses to rethink the ownership structure.
The following parts of the study contains the results of research on ownership structure of family owned businesses. The examined family businesses are interested in long-term preservation of values, thus succession of generations plays a key role in their case. They attaches great importance how the ownership structure develops.

\section{MATERIAL AND METHOD Analysed Family Businesses}

The focus area of the research is the examination of successful operation of family owned businesses from agri-food sector. To know more about the operation of family businesses 11 expert interviews were made between november 2016 and october 2017 with owners and next-generations of family owned agri-food enterprises.

A case study has been prepared too in this topic with the participation of companies with different activities (production, service, trade). There are 3 companies who took part in both research methods (Master Good Group, Tatár Bakery Ltd., V-Trade Ltd.). In their case the statement is the same according to both approach. The illustration the result was built on the expert interview (Table 1).

The question framework of expert interviews included questions about the ownership structures. The current ownership sturcture has been stated in case of analysed FBs. The information about the ownership structure based on the contatnt of the official bylaws of each analysed family owned company. The results show current sturcture of ownership. The table below (Table 1) shows the relevant information about analysed enterprises.

\begin{tabular}{|c|c|c|c|}
\hline Method & $\begin{array}{l}\text { Name and form of FB } \\
\text { (Ltd./LLC , PLC) }\end{array}$ & Generation & Activity \\
\hline \multirow{11}{*}{ Expert interview } & Aqua Plastech LLC & 2 & \multirow{11}{*}{$\begin{array}{l}\text { agri-food } \\
\text { enterprises }\end{array}$} \\
\hline & Bold Agro LLC & 2 & \\
\hline & Flavon Group Ltd. & 2 & \\
\hline & Gál Tibor Winery & 2 & \\
\hline & Heimann Winery & 2 & \\
\hline & La Fiesta LLC & 1 & \\
\hline & Master Good Group & 2 & \\
\hline & Szamos Marzipan LLC & 3 & \\
\hline & Tatár Bakery Ltd. & 2 & \\
\hline & $\begin{array}{l}\text { Tranzit Group } \\
\text { (Tranzit-Ker PLC) }\end{array}$ & 2 & \\
\hline & V-Trade Exhibitions Ltd. & 2 & \\
\hline \multirow{3}{*}{ Case study } & Krajcár Packaging Ltd. & 2 & \multirow{3}{*}{$\begin{array}{c}\text { production, } \\
\text { service, } \\
\text { trade }\end{array}$} \\
\hline & Pata József Machinery Ltd. & 2 & \\
\hline & Vivaco LLC & 2 & \\
\hline
\end{tabular}

1 According to Hungarian Statistical Office both the Ltd. and LLC means the same, limited-liability company. Basically the abbreviation of LLC was used except in case of those companies who has an own english name. (The sources of the english names are the companies websites. 
The column of the Table 1. named "generation" shows the current state of the FB. The number indicates which generation is present in the business in 2017. The first generation nearly in all cases are the founder thus the first generation is the founder generation in Hungary. There are one analysed company which is a third generation enterprise (Szamos Ltd.). Typically, the second generation are active in Hungarian FBs nowadays after historically significant changes in business economics.

\section{Examination criteria of analysed family businesses}

It was necessary to work out a criteria for the clear classification of generations of examined enterprises. Six categories were developed to classify FBs. Table 2. lists the categories and main characteristics of each ownership level. The characterization based on various criteria like:

- age group category of next generation (MiniGen, JuniorGen, Discoverer, Owner/New manager $)^{2}$,

- family links (wife, husband, children, new family member(s), sibling(s), cousin(s)),

- ownership proportion according to articles of association.

Furthermore there are some common criteria which shall be

taken into account, such as:

- the number of family members (parents, children, family links),

- the number of family members which divides the possession,

- the number of family members in top management,

- the number of family members in management,

- the exact proportion of ownership,

- the number of external owners, shareholders.

Table 2. The main characteristics of ownership categories ${ }^{3}$

\begin{tabular}{|c|c|}
\hline $\begin{array}{l}\text { Name of owner- } \\
\text { ship category }\end{array}$ & The main features of the categories \\
\hline $\begin{array}{l}\text { 1.Non-owner } \\
\text { (NO) }\end{array}$ & $\begin{array}{l}\text { - MiniGen (less than } 14 \text { years old) } \\
\text { - Wife/husband/new family member(s) } \\
\text { - No ownership proportion ( } 0 \% \text { proportion) } \\
\end{array}$ \\
\hline $\begin{array}{l}\text { 2.Emotional } \\
\text { owner (EO) }\end{array}$ & $\begin{array}{l}\text { - MiniGen (less than } 14 \text { years old) } \\
\text { - JuniorGen (between } 14 \text { and } 18 \text { years) } \\
\text { - Wife/husband/new family member(s) } \\
\text { - Emerging collective psychological feeling (F-CPO) of } \\
\text { ownership (0\% proportion) (Rantanen-Jussila, 2011) }\end{array}$ \\
\hline $\begin{array}{c}\text { 3.Partial } \\
\text { owner (PO) }\end{array}$ & $\begin{array}{l}\text { - Discoverer (more than } 18 \text { years old) } \\
\text { - Owner/new manager (more than } 25 \text { years old) } \\
\text { - Family members (head of the family, sister(s), brother(s)) } \\
\text { - Wife/husband,new family member(s) sibling(s), cousin(s) } \\
\text { - Has } 0 \%-49 \% \text { ownership proportion }\end{array}$ \\
\hline $\begin{array}{l}\text { 4.Controlling } \\
\text { owner (CO) }\end{array}$ & $\begin{array}{l}\text { - Discoverer (more than } 18 \text { years old) } \\
\text { - Owner/new manager (more than } 25 \text { years old) } \\
\text { - Head of the family } \\
\text { - Wife/husband/new family member(s) } \\
\text { - has proportion more than } 50 \% \text { of ownership and is in a } \\
\text { leading position }\end{array}$ \\
\hline $\begin{array}{l}\text { 5.Majority } \\
\text { owner (MO) }\end{array}$ & $\begin{array}{l}\text { - Discoverer (more than } 18 \text { years old) } \\
\text { - Owner/new manager (more than } 25 \text { years old) } \\
\text { - Head of the family } \\
\text { - Has a high proportion of ownership (more than } 50 \% \text { ) }\end{array}$ \\
\hline $\begin{array}{c}\text { 6.Sole } \\
\text { owner (SO) }\end{array}$ & $\begin{array}{l}\text { - Discoverer (more than } 18 \text { years old) } \\
\text { - Owner/new manager (more than } 25 \text { years old) } \\
\text { - Head of the family } \\
\text { - The exclusive/sole owner of the business }(100 \%)\end{array}$ \\
\hline
\end{tabular}

Source: own work
The most questionable category is the emotional owner. The member of the next generation becomes an emotional owner when he/she starts to feel that the company plays an important role in the life of the family and thus starts to help to operate the business at least in a low level.

The following table (Table 3.) contains the theoretical coherence between the typical ownership categories, the next generation's age, the degree of responsibility (low, medium, high) and the senior's working activity. If the next generation already works in the company the senior - who is typically the founder the company in case of interviewed enterprises - can be classified into three groups according to the degree of working activity. Actively working (AW), activity decreasing (AD) and there are some cases when the previous generation is not presented (NP). The event determining activity level of the senior could be suddenly and unexpectedly or consciously.

Table 3.

Theoretical contexts of NextGen, Senior, responsibilities and ownership

\begin{tabular}{|c|c|c|c|c|c|}
\hline Name & \multicolumn{5}{|c|}{ Categories } \\
\hline $\begin{array}{l}\text { Next generation } \\
\text { (name, age) } \\
\text { (children) }\end{array}$ & $\begin{array}{c}\text { MiniGen } \\
\text { (less than } 14 \\
\text { years old) }\end{array}$ & $\begin{array}{c}\text { JuniorGen } \\
\text { (between } \\
14 \text { and } 18 \\
\text { years old) }\end{array}$ & $\begin{array}{c}\text { Discoverer } \\
\text { (more than } \\
18 \text { years } \\
\text { old) }\end{array}$ & $\begin{array}{r}\text { Own } \\
\text { ma } \\
\text { (more } \\
\text { yea }\end{array}$ & $\begin{array}{l}\text { Inew } \\
\text { ger } \\
\text { an } 25 \\
\text { old) }\end{array}$ \\
\hline $\begin{array}{l}\text { Ownership } \\
\text { categories }^{4}\end{array}$ & \multicolumn{2}{|c|}{$\begin{array}{l}\text { NO } \\
\text { EO }\end{array}$} & \multicolumn{3}{|c|}{$\begin{array}{c}\text { EO } \\
\text { PO } \\
\text { CO } \\
\text { MO } \\
\text { SO }\end{array}$} \\
\hline $\begin{array}{l}\text { Responsibility, } \\
\text { Management, Inde- } \\
\text { pendence }{ }^{5} \\
\text { (independent } \\
\text { management, inde- } \\
\text { pendent decision- } \\
\text { making, the degree } \\
\text { of responsibility) }\end{array}$ & $\mathrm{L}$ & $\mathrm{L}$ & M & $\mathrm{M} / \mathrm{H}$ & $\mathrm{H}$ \\
\hline $\begin{array}{l}\text { Senior (working } \\
\text { activity) } \\
\text { (parents) }\end{array}$ & \multicolumn{3}{|c|}{ AW } & \multicolumn{2}{|c|}{$\begin{array}{l}\mathrm{AD} \\
\mathrm{NP}\end{array}$} \\
\hline
\end{tabular}

Source: own work

2 The classification of age groups are built on the NextGen Strategy of FBN-H (2014).

3 These are generalized characteristics. There are many dif ferent cases in practice.

4 Ownership category abbreviations have been applied, indicated in Table 2.

$5 \mathrm{~L}=$ low, $\mathrm{M}=$ medium, $\mathrm{H}=$ high

$6 \mathrm{AW}=$ actively working, $\mathrm{AD}=$ activity decreasing, $\mathrm{NP}=$ not present. 
The next chapter specialize the examined FBs to ownership classification in the light of successive generations and shows the contexts with the currently working generations. There are indicating which generation is presented in the business activity during the period of research. In the case of interviewed FBs the second generation are the children and third generation are the grandchild of the first generation. The table highlights the relation of the next gen's responsibility and the senior generation's working activity.

\section{RESULTS AND DISCUSSION}

In the last year during a theoretical research it was identified that there is "also a great quantity of international literature and case studies available, at the same time there is not much national experience, applied method and database to use" (TOBAK NÁBRÁDI, 2016). For the purpose to expand the Hungarian practical knowledge about family owned businesses 11 interviews and a case study were made. The theoretical and practical context of the Hungarian practice is summarized in Table 4.

Table 4.

Theoretical and practical contexts based on the Hungarian results ${ }^{7}$

\begin{tabular}{|c|c|c|c|c|c|c|}
\hline \multirow{2}{*}{ Name of FB } & \multirow{2}{*}{$\begin{array}{c}\text { Gen- } \\
\text { erations } \\
\text { (involved } \\
\text { in entre- } \\
\text { preneurial } \\
\text { activity) }\end{array}$} & \multicolumn{3}{|c|}{$\begin{array}{l}\text { Ownership category of } \\
\text { succesive generations }\end{array}$} & \multirow{2}{*}{$\begin{array}{c}\text { Responsibil- } \\
\text { ity, Manage- } \\
\text { ment, Inde- } \\
\text { pendence } \\
\text { NEXT GEN }\end{array}$} & \multirow{2}{*}{$\begin{array}{l}\text { Working } \\
\text { activity }^{6} \\
\text { SENIOR }\end{array}$} \\
\hline & & $\begin{array}{l}1^{\text {st }} \\
\text { gen }\end{array}$ & $\begin{array}{l}2^{\text {nd }} \\
\text { gen }\end{array}$ & $\begin{array}{l}3^{\text {rd }} \\
\text { gen }\end{array}$ & & \\
\hline $\begin{array}{c}\text { Aqua Plastech } \\
\text { LLC }\end{array}$ & 1,2 & SO & NO & - & M & AW \\
\hline $\begin{array}{l}\text { Bold Agro } \\
\text { LLC }\end{array}$ & 1,2 & $\mathrm{PO}$ & $\mathrm{PO}$ & - & $\mathrm{H}$ & AW \\
\hline $\begin{array}{l}\text { Flavon Group } \\
\text { Ltd. }\end{array}$ & 1,2 & $\mathrm{PO}$ & $\mathrm{PO}$ & - & $\mathrm{H}$ & AW \\
\hline $\begin{array}{l}\text { Gál Tibor } \\
\text { Winery }\end{array}$ & 2 & NO & MO & - & $\mathrm{H}$ & NP \\
\hline $\begin{array}{l}\text { Heimann } \\
\text { Winery }\end{array}$ & 1,2 & $\mathrm{PO}$ & $\mathrm{PO}$ & - & $\mathrm{L}$ & AW \\
\hline La Fiesta LLC & 1 & SO & - & - & $\mathrm{L}$ & AW \\
\hline $\begin{array}{l}\text { Master Good } \\
\text { Group } \\
\end{array}$ & 1,2 & $\mathrm{PO}$ & MO & - & $\mathrm{H}$ & $\mathrm{AD}$ \\
\hline $\begin{array}{l}\text { Szamos Marzi- } \\
\text { pan LLC }\end{array}$ & 2,3 & NO & $\mathrm{PO}$ & $\mathrm{PO}$ & $\mathrm{H}$ & $\begin{array}{l}\text { 1st NP } \\
\text { 2nd AD }\end{array}$ \\
\hline $\begin{array}{l}\text { Tatár Bakery } \\
\text { Ltd. }\end{array}$ & 2 & $\begin{array}{l}\text { under } \\
\text { nego- } \\
\text { tiation }\end{array}$ & $\mathrm{PO}$ & - & $\mathrm{H}$ & NP \\
\hline $\begin{array}{l}\text { Tranzit Group } \\
\text { (Tranzit-Ker } \\
\text { PLC) }\end{array}$ & 1,2 & MO & $\mathrm{PO}$ & - & $\mathrm{H}$ & AW \\
\hline $\begin{array}{l}\text { V-Trade Exhi- } \\
\text { bitions Ltd. }\end{array}$ & 1,2 & MO & $\mathrm{PO}$ & - & $\mathrm{H}$ & AW \\
\hline $\begin{array}{l}\text { Krajcár Pack- } \\
\text { aging Ltd. }\end{array}$ & 1,2 & MO & $\mathrm{PO}$ & - & $\mathrm{L}$ & AW \\
\hline $\begin{array}{l}\text { Pata József } \\
\text { Machinery } \\
\text { Ltd. }\end{array}$ & 1,2 & MO & EO & - & $\mathrm{H}$ & $\mathrm{AD}$ \\
\hline Vivaco LLC & 2 & MO & NO & - & M & AW \\
\hline
\end{tabular}

7 Abbreviations have been appled according to Table 2. and Table 3.
Based on the results it can be concluded that the property even are sharing within family in case of the analysed family owned companies. There are only two interviewed companies whose case we can talk about exclusive/sole ownership.

The international and national practice shows a specific context. When the activity is decreasing (AD) the senior starts to pass the rights of independent management and decisionmaking to the next generation. The proportion of ownership and the responsibility is growing at the same time.

In general where the responsibility of the next gen is medium or low $(\mathrm{M} / \mathrm{L})$, the senior generation is working actively (AW) and the larger ownership proportion is in the hand of the senior generation in the most analysed cases (Aqua Plastech LLC, Heimann Winery, La Fiesta LLC, Krajcár Packaging Ltd., Vivaco LLC). In case of the other analysed companies the high $(\mathrm{H})$ responsibility is accompany with decreasing working activity of the senior generation and more divided ownership proportion. In these cases the next generation typically is in the age category of "Owner/new manager" which means they have more than 25 years old.

Concerning the analysed enterprises most of the successors are family members. However there are one case (La Fiesta LLC) where the founder owner was forced to educate the appropriate successor from among the employees.

As in the introduction part was mentioned there are unexpected events which forces the family businesses to rethink the ownership structure. The events like birth, death, marriage, divorce or retirement are unpredictable and may upset the family balance. For example in case of Tatár Bakery Ltd. happened a family and business crisis. The majority owner and founder of the company died in the last year that is why only the 2nd generation is involved in the entrepreneurial activity. The Tatár Bakery's second generation belongs to the partial owner (PO) category instead of category of controlling owner (CO).The change in the article of association it is still under negotiation (question of inheritance). In their case the next generation (2nd generation) has high responsibility and the senior is not presented. For instance another story of Gál Tibor Winery is a positive example to show how it is possible to resume again after a family and business tragedy with cooperation and with a lot of work.

Each company has an own story and in the life of family firms maybe it has more importance. In case of them beyond the family tragedy and crisis there are a business and financial crisis. The stability and the security of the family and the business becomes questionable which means a financial instability in the life of the family.

Since the change of the regime passed nearly 30 years in Hungary. It means that it is a time to pass the baton (NÁBRÁDI et al., 2016) together with responsibilities and ownership proportion in case of the most analysed company. The legal regulation and the possibility to share the ownership proportion makes this process easier.

In line with international practice to become a manager, top manager or controlling manager and owner from the next generation it is necessary to work in another company and gain more experiences. These kind of learning process is 
mainly contributing to become a great successor and leader, and perform the leadership tasks well.

FB researches are related with many disciplines as to anthropology, economic science, social psychology, sociology and psychology. Because of the diversity of the topic further research and analytical work is needed to outline a Hungarian situation. It would be an interesting research direction the question of social categories in connection with succession. During the conscious generational transfer within family it is necessary to take into account the social generational differences.

\section{REFERENCES}

Arregle, J-L., Naldi, L., Nordqvist, M., \& Hitt, M. A. (2012). Internationalization offamily-controlled firms: A study of the effects of external involvement in gov-ernance. Entrepreneurship Theory and Practice, 36(6), 1115-1143.

Calabrò, A., Campopiano, G., Basco, R., \& Pukall, T. (2016):

Governance structureand internationalization of family-controlled firms: The mediating role of inter-national entrepreneurial orientation. European Management Journal,. Availablefrom: http://www.sciencedirect.com/science/article/pii/ S0263237316300548(20.05.16).

Carlock, R. S. (2012): Past, present, future: passing the baton to a new generation. The Times, 4 Oct 2012. http://theraconteur.co.uk/ past-present,-future-passing-the-baton/ (28.10.2012)

Chu, W. (2011): Family ownership and firm performance: Influence of family management, family control, and firm size. Asia Pac J Manag 28. 833-851 pp.

Csákné Filep J. (2012): Családi vállalkozások - Fókuszban az utódlás, Budapesti Corvinus Egyetem, Gazdálkodástani Doktori Iskola, Ph.D. disszertáció

De Massis, A., Sharma, P., Chua, H. J., Chrisman, J. J., \& Kotlar, J. (2012). Family business studies: An annotated bibliography.

Cheltenham: Edward Elgar.

FBN-H (2014): Nextgen stratégia 2014

Giovannini, R. (2010): Corporate governance, family ownership and performance. J Manag Gov 14. 145-166 pp.

Mandl, I. (2008): Overview of Family Businesses Relevant Issues, Final report, KMU Forschung Austria, The study was conducted on behalf of the European Commission, Enterprise and Industry Directorate-General, p.175

Cano-Rubio, M., Fuentes-Lombardo, G., Carlos Vallejo-Martos, M. (2017): Influence of the lack of a standard definition of "family business" on research into their international strategies. European Research on Management and Business Economics 23 (2017). pp. 132-146.

Nagy A. (2007): Analysis of the Expected Income of several family types, Apstract, (Applied Studies in Agribusiness and Commerce) Vol. I (1) pp. 49-51.

Nábrádi A., Bárány L., Tobak J. (2016): Generációváltás a családi tulajdonú vállalkozásokban: Problémák, konfliktusok, kihívások, elméleti és gyakorlati megközelítés. Gazdálkodás 5: pp. 427-461.

Ramadani, V., \& Hoy, F. (2015). Context and uniqueness of family business. In L. P. Dana, \& Ramadani (Eds.), Family businesses in transition economies. Springer

Rantanen, N. - Jussila, I. (2011): F-CPO: A collective psychological ownership approach to capturing realized family influence on business. Journal of Family Business Strategy 2. 139-150 pp.

Tobak J., Nábrádi A. (2016): The theoretical approach to succession of family businesses. Annals Of The Polish Association Of

Agricultural And Agribusiness Economists XVIII:(4) pp. 224-230. 
